\title{
Exploring Saudi Arabia's EFL Student Identity: A Narrative Critical Approach
}

\author{
Tariq Elyas \\ European Languages Department \\ King Abdulaziz University, Jeddah, Saudi Arabia \\ E-mail: telyas@kau.edu.sa
}

Received: 08-03-2014

doi:10.7575/aiac.ijalel.v.3n.5p.28
Accepted: 28-04-2014

Published: 01-09-2014

URL: http://dx.doi.org/10.7575/aiac.ijalel.v.3n.5p.28

\begin{abstract}
This article explores the English Foreign Language (EFL) learning identities of first year Education students against the backdrop of post 9/11 Kingdom of Saudi Arabia (KSA). The study makes use of narrative analysis (Benwell \& Stokoe, 2006) identifying the types of stories (master narratives) the respondents identify with, as well as how they perform their identities within these stories. The data indicate that in contrast to conservative forces within Saudi Arabia that promote a fixed Islamic/Arab identity, the student respondents firmly aligned themselves with master narratives relating to globalisation, the information age and individuality, thus pre-empting educational reforms. This study is significant since it highlights the complex learning identities of Arab youth and the need for a more sophisticated curriculum development within this context.
\end{abstract}

Keywords: Learning identities, global identity, discourse analysis, EFL, narrative approach, story-telling

\section{Introduction: Conflicting Discourse and Identity}

The post 9/11 decade in the Kingdom of Saudi Arabia (KSA) has been characterised by calls for socio-political reform both from outside and within the Kingdom. The homogenising, globalising effect of the World Wide Web has similarly contributed to the movement towards reform. However, conservative backlash against any change to the status quo has been equally strong. Education has been an area of particular emphasis. While some voices within KSA such as Prince Khalid Al-Faisal on his weekly program Idhaat on Al-Arabiya TV (2004) have acknowledged that the KSA school curriculum and (even more particularly) the "hidden curriculum" may foster "extremism and violence", others have just as vehemently denied the charges. For example, in the Al-Watan newspaper, Muhammad Al-Najimi, a member of the Islamic Figh (Jurisprudence)Academy, stated, as reported by Azuri (2006, p.1), "some of the calls for curricula change harm national principles, and this threatens national identity. There are those who argue that our curricula contain Takfir [accusations of apostasy against other Muslims], as there is a religious spirit to some of the content, but the truth is that there is not a single word calling for Takfir in the curricula, and the curricula adhere to Islam and not to any particular religious group" (as cited by Alzuri, 2006, p.1). Azuri (2006) further reports of an Islamic website with a petition by 61 KSA Sheikhs, university presidents, professors, attorneys, judges and educators who warned that a "Junta" had taken over KSA education in order to "westernise" KSA society. He notes that they called on the KSA rulers to stop these reforms and warned against such "deviant westernizing tendencies" (Azuri, 2006, p.1).

In contrast to these competing voices, government officials such as the Saudi Minister of the Interior, Prince Naif Ibn Abd Al-Aziz have attempted to reconcile the disparate positions stating: "We do believe in the soundness of our educational curriculum, but we never oppose development of educational methods in a manner that does not run counter to the country's deep-rooted principles" (as cited by Elyas, 2008a, p.31).

This environment of rapid changes and conflicting public discourses is likely to challenge teachers' performance of their professional identities and likewise influence students' learning identities. A recent study of female Islamic Studies teachers in KSA by Jamjoon (2010) highlighted the complex KSA teaching identity where teachers must negotiate "the growing contradictions between societal practices and religious doctrine" (Jamjoon, 2010, p.56). Several studies dealing with English language policy in the past decade (Al-Issa, 2006; Clarke, 2006, 2008a, 2008b, 2009, 2010) have shown that English policy reform, as in the case of Islamic Studies, has had an unsettling effect on teaching and learning identities in this volatile context (Clarke, 2008a). The struggle of competing discourses raises the question on how to "reconcile the competing demands of local, regional, national and religious identities with the homogenizing tendencies of globalization and English" (Canagarajah, 1999, p. 76).

In 2007, the KSA Ministry of Education launched an education project entitled Tatweer (Modernization). This ambitious project, which is forecast to end in 2013, has been allocated an estimated \$293 million (Al-Degether, 2009). Its emphasis is on the introduction of information technology into school curricula and activities, and developing infrastructure and teacher's skills to support this technology (Tatweer, 2010), thus further encouraging the globalising effects of the World Wide Web. Although the project has a neo-liberal focus, attempting to equip public school students 
with information technology skills to participate in an increasingly globalised society, it attempts to preserve the values and ideologies underpinning Saudi society (Tatweer, 2010).

This paper explores the narratives of male students from two English language classes at one KSA university as a way into understanding their identities within their learning context. It aims to ascertain whether their learning identities have changed as a result of policy changes post 9/11. Identity is of a particular interest here as these young KSA English students are English-teachers-in-training who will be faced with implementing the new policies such as the Tatweer in public schools.

\section{Methodology: Narrative Design and Data}

The narrative theory has found an important place in educational theory in recent years because of its ability to unpack and understand the internal 'truths' of individuals. Bakhtin (1981) argued that narratives are a particularly useful way of revealing identity since in narratives individuals are "always making themselves, as always able to render untrue, any definite version of identity" (Bakhti1981: p.37). This aspect is of particular importance for students learning English as a foreign language or English as an additional language (EFL/EAL) since, as noted by Pavlenko, "The [D]iscourse of native speakerness exerts a price on those who believe that in order to validate their personal and professional identities they need to enter their imagined community... The self-positioning as a NNS and oftentimes as a perpetual L2 learners is an unavoidable corollary of internalization of the dominant SLA discourse, which portrays L2 learning as neverending and elusive for NS competence" (Pavlenko, 2001, p.259). Within this environment where the ESL/EAL learner is likely to feel marginalised and 'othered', it is important to encourage a sense of identity through the telling of "language learning narratives" (Roberts, 2002, p.3), since as highlighted by Schiffrin (1996: p.167), "narrative, self, identity, gender, family, and speech all act as a resource for the display of self and identity".

The data for this study consists of the language learning narratives of English majors in their first year of study. KSA students' language learning narratives at this point of history are of particular interest since they are constructed within a 'glocalization' (Khondker, 2004) platform where the students are experiencing both local and global pressures which shape their identities. These respondents were also selected since they are transitioning from learning English in High School to studying the language at a university level, and from being high school students themselves to their eventual roles as English teachers in KSA high schools. The narration of life stories related to key transitions are vital for gaining insight into language learning identity (Chhuon, Kyratzis, \& Hudley, 2010) and how their identities are influenced by the materials (in this case the Interactions I and Mosaic I textbooks), the changes in policy and the pedagogy they experience. These respondents therefore provide insight into the views of KSA youth at a key transition point in the country's Education system and into the individual transitions of teachers-to-be.

Narrative theorists suggest that, since "we live in a storytelling society through which we make sense of our lives" and "selves and identities are therefore constituted in talk", it is important to "examine the kind of stories narrators place themselves within", how their identities are "performed and strategically claimed", and why "narratives are developed in particular ways and told in particular orders" (Benwell \& Stokoe, 2006, pp.42-43). Thus to explicate participants' narratives, narrative theorists divide their research into two distinctive steps: First, they familiarise themselves with the structure and content of the narrative, and describe the narratives in terms of "beginnings, middles, ends, narrative linkage and subplots connected to the overall narrative" (Murray, 2003, cited in Benwell \& Stokoe, 2006, p.144). In the second phase, "the focus is on interpretation which involves connecting the broader theoretical literature to the participants' stories" (Murray, 2003 cited in Benwell \& Stokoe, 2006, p.144). This second phase relates to what Gee (1996; 1999a; 1999b) calls "Discourses" and what Benwell and Stokoe refer to as "master narratives" (2006, p.43). However, this kind of research along with Critical Discourse Analysis, has been criticised for "taking identity categories for granted", and taking a top-down approach (Benwell \& Stokoe, 2006, p.45). To combat this criticism, this research takes both a top-down and a bottom-up approach. The bottom-up approach is reflected in the detailed structural and discourse analysis and interpretative stance towards the data, while the top-down approach identifies the content and structure of the narratives, and relates the Discourse/Master narratives to Discourses/ Narratives identified in the literature.

The exploration of the students' narratives aims to thematise the self and the identity presented in their EFL autobiographies. In order to do this the students were requested to write personal narratives in response to the following prompts:

- $\quad$ Narrative Prompt (NP): Tell the story of what you believe has influenced your language learning in your life in general?

- NP2: Tell the story of what you believe has influenced your language learning in the University and other educational environments?

- NP3: Describe your feelings about your level of English?

\subsection{The Types of Stories Narrators Place Themselves}

The way the respondents structured their narrative provides insight into the students learning story and language learning identity. Twenty-three students volunteered to write language learning narratives with one excluded since it did not relate to the prompts presented. Despite the order of the prompts above, most of the student narratives began with NP3 focussing on their feelings related to their level of English. Solomonides and Reid (2009) stated that "it is easy to underestimate the importance of students' feelings of happiness and confidence in relation to their pre-professional 
learning experiences" (p.8). Also, Deci \& Ryan emphasised the importance of students' feelings and their experiences of the social surroundings in the development of their language learning identity (Scott Rigby, Deci, Patrick, \& Ryan, 1992). This is perhaps why the respondents mostly started their narratives with their feelings towards their level of English and (in some cases) towards the learning of English in general.

Broadly, the student narratives can be divided into 'success stories' (referring to their perception of their level of English as satisfactory) and 'failure stories' (referring to a perception of an unsatisfactory level of English).

2.1.1. The Structure of the Success Story

\subsubsection{Beginnings}

Of the 22 respondents, nine are defined as 'success stories'. The beginnings of the 'success story' narratives can broadly be divided into two categories: satisfaction with English and the importance of English. The feelings of satisfaction with English appear to be due to satisfaction with their level of English or pride in their own work ethic.

\subsubsection{The Media as a Vehicle to Improve Students' English}

Karam (2010) argues that "the role of the media as a venue for informal education for young people has so far largely been neglected in our understanding and youth in the Arab region" (p. 305). Most of the research on media in the Arab region has focused on the 'clash' of the two civilizations (Fakhro, 2006). Few in the region have explored the role of the media and its effect on the educational level on the youth as noted by Al-Shuaibi (2006). Karam (2010) argues that "the increasing influence of satellite television is probably the single most important development in the Arab media for the past fifteen years" (p. 303) and is a particular area for research in terms of education.

A few studies have focused on the role of the media in EFL in KSA (Elyas, 2008a, 2008b, 2008c, 2008d, 2009a, 2009b). This research links some of the students' experiences with the media and how it has positively impacted their level of English. As is indicated by the studies mentioned-above, it appears that the media, particularly satellite television and the Internet, played an important role in the respondents in this study's English success stories. A number of the respondents ascribed their success and consequent satisfaction with their level of English to their exposure to the English media. For instance, Student 9 ascribed his good level of English to the influence of the media, "I think I am satisfied (sic) with my English level learning" [Line 1-3] to the role of the media "since I was a kid when I was nine years old by watching T.V. (sic) until I has took (sic) English class in the secondary schools (s)". Student 3 asserted that "you can improve yourself at home by watching American movies or something like that" [Line 9-10]. Student 17 likewise advised his friends "to watch moves (sic) as much as you can" [Line 9-10]. Similarly, Student 19 claimed that the reason he knows English is from "watching TV" [Line 7] and Student 21 stated that students should "wating (sic) anything by English" [Line 14]. Student 22 used a broader range of media to improve his English and stated that his success was because, "I read English newspaper and I read comic books. I see (sic) English movies and English T.V. Channel" [Line 5-7].

Some other students, such as Student 6 took a more intellectual approach towards the media and emphasised the quality of the media as well as the quantity of access to media. This student stated that he "read(s) newspaper that one of a way (sic) to more about English" [Line, 4-5]. Student 16 likewise accessed newspapers as well as "good books" [Line 1315]. He also advised his fellow students to try to "hear native speakers on the radio or T.V. like BBC Channel. Read newspaper, magazines and short stories" as well as "listen to English radio stations and watch English programs and movies" [Line 21-22]. Student 16's approach to improve his level of English stemmed from his intellectual awareness of what was classified as 'good' books and 'good' English programs according to him. In his case he listed watching movies as the last option on his list.

One respondent, Student 3, started his success story ("learning English is easy, am satisfied with my level of English"[Line 1-2]) with the acknowledgement that learning English through exposure to the media was not easy, but "they [his ways of learning] take a lot of time and efforts" [Line 2-3]. Another respondent, student 18 indicated that exposure to a variety of media was necessary and that students should try to "practise (sic) all these [English skills] by internet, chat, messenger" [Line 18-19].

In the case of three of the success stories, the narratives started with a response to Narrative Prompt (NP) 2, i.e. influences on their attitudes to the language rather than their feelings about the language. In these cases, in particular, the respondents were dismissive of classroom experiences as reflected in the comment: "students cannot learn English only inside classes. They should use English everywhere" [Student 15, line, 10-11]. It seems that these students found 'refuge' in watching TV programs, online chatting, and media explore which enabled them to further develop their English skills, access information and interact with other young people. Their positive attitude towards learning via the popular media is supported by theorists such as Giddens (1993) who argued that "TV watching even of trivial programmes, is not an inherently low-level intellectual activity; young people 'read' programmes by relating them to other systems of meaning in their everyday lives" (p. 451).

In these narratives, in particular, the master narrative of the superiority of immersive language acquisition is evident (Karam, 2010). In relation to English language teaching this master narrative is of course a hotly debated topic with many modern theorists following Krashen $(1981 ; 1985)$ and Halliday $(1983,2003$;) with the view that language cannot be acquired solely through immersion after childhood and that conscious learning is required. This theory seems to clash with the respondents' views that English can be fully acquired solely through accessing the media. 
This fascination with the media is looked at with a critical and concerned eye by many in the Arab world. For example, Al-Shuaibi (2006 : p. 153).) warned that: "Television ....can help either support existing value systems or to shatter cultural and value barriers. This fact imposes a massive responsibility on the media, not only in educating children and youngsters, but in educating society as whole." On the other hand, Giddens (1993: p. 446). ) argued that this view is marginal as he believed that "this is not just because they [mass media] affect our attitudes in specific ways, but because they are the means of access to the knowledge on which many social activities depend" For the students in this study, the media was not just a way of improving their English, but also as Giddens suggested vital to their access of knowledge and social interaction as reflected in the following student comment: "leaning English give (sic) many chances" [St21, Line, 2-3] and access to global language for business as in "people prefer [it] in conference and business" [St4, Line, 2-3], and a language to access knowledge in different culture as "it gives you the chance to discover new cultures, habits, and people from different culture" [St15, Line, 1-2].

This emphasis on the media as a means to access information is highlighted in the Tatweer documents where the focus is on "manufacturing an educational curriculum with a leading interactive high-technology" (Tatweer Vision, 2010). Although the role of English in this digital 'information age' is not explicitly mentioned in the Tatweer or any other policy or curriculum documents, the students obviously are aware of digital information sources and feel at home as "digital natives" (Bennett, Maton, \& Kervin, 2008) in this environment as indicated by the following comment: "use websites" [St 4, Line, 14] or hear English radio "like BBC" [St15, Line14].

These same learners also seem to reflect a master narrative that suggests that the English of Anglophone countries is in some way superior and that effective acquisition can only take place when interacting with people from these target countries, as reflected in the following statements by Student 16: "the easiest way [to improve our English level] is by speaking with as native English speakers" [12-14]. Likewise, Student 6 believes that "having English speakers as friends helps a lot" [Line, 8]. Also, Student 19 states that" English language is the world language" [line, 16] and Student 4 as in "people prefer (sic) in conference and business talk" [Line, 2-3].

\subsubsection{The Myth of English as an International Language}

The above statements link with the master narrative or "myth" of "English as an International Language" (Pennycook, 1994, p.26) which emphasises the importance of "standard' varieties above the concept of "World Englishes" (Canagarajah, 2005; Kachru, 1997).

The three respondents who started their success narratives by emphasising the importance of English appear to support this 'myth'. They ascribe huge economic and business importance to English as is indicated in the following words "it's Universal language" [St21, Line4] that gives you "many chances" [St21, Line3] as in "conferences and business" [St4, Line2-3] in order to "communicate with the whole world" [St4, Line3-4]. Pennycook claims that English "holds out promise of social and economic development to all 'those' who learn it; and that English is a language of equal opportunity (1994, p.26). This perception is evident in the students' narratives. For example, Student 15 points out the importance of English and his fascination with the new adventures it can bring him. He believes that "it [English] gives you a chance to discover new cultures, habits and new people from different cultures" [Line 1-2] and "it requires a business market" [Line, 5-8]. He further states the importance of English for economic success in "in my country you should be very good in English if you want a good job" [Line 3-4]. Likewise, Student 18 reflects the same idea by stating that "at these days English language becomes international. We need it in our life like jobs, business, (sic) games and so on" [Line, 3-5]. Hence, it is of no surprise that many of these students believe that the "English language is the world language" [Student 19, line, 16]. Student 22 links his individual future prosperity with English and states "we can have a good future" [Line, 17].

As Pennycook (2005) points out, "English is deeply embedded in a set of social, cultural, political and economic relations" (p. 158). These students, however, unsuspiciously appear to accept the importance of English in all these spheres. Their valuing of English and participation in the English-dominated media has brought economic and 'social capital' (Bourdieu, 1986) that appears to be part of their success stories. One can argue that it seemingly that there is no resistance to English as a "missionary language" (Pennycook \& Coutand-Marin, 2003) or suspicion of linguistic imperialism (Phillipson, 1992). Instead, they can only see the promise learning English holds for them. Student 20, for example, believes that "learning English gives students many chances or different chances. We are studying English because it's Universal language" [Line, 2-4]. Also, Student 5 states 'English now should (sic) everyone learn because it's very important in job, business" [Line, 14-15]. It is apparent that the above students are firm believers that 'English as a Universal language' can bring them unlimited chances for a better future. In this attitude, they are similar to the respondents in Al-Haq's and Smadi's studies in the late 1990s that appeared to view English as neutral and not “imperialistic oriented," (Al-Haq \& Smadi, 1996, p. 6).

It could be argued, however, that with the increased and increasing access to the internet and Satellite T.V for KSA citizens in the 21 st century, especially post-9/11, global, imperial forces have had easier access to conservative KSA society than ever before and that this should not be accepted uncritically. The idea of the 'international', 'universal' and the 'world language' colludes with globalization and as Tsuda (cited in Phillipson, 1999) notes this results in "an uncritical endorsement of capitalism, its science and technology, a modernisation ideology...ideological globalisation and internalisation, transnationalisation, the Americanisation and homogenisation of world culture, linguistics, culture and media imperialism" (p. 274). The students' simplistic view of English as a 'ticket' for a better life, a better future and economic prosperity in a globalized world could potentially, as Tollesfon (2000) warns, " contribute to significant social, political, and economic inequalities" (p. 8). 
Perhaps it is this emphasis on the importance of English which has resulted in large numbers of students at KAU choosing English as a major. According to the www.teachingenglishinsaudarabia.com website, enrolees in ESL classes have increased due to the improving economy in the status, as there has been increase in service industry employment that requires more workers to work for hotels, health institutions and airports. Also, the kingdom is now actively promoting an English curriculum to be integrated with the country's educational program. There are many ways why Saudis would like to learn English. The most notable reason is that the English would help them advance their career. Also, there has been an increased demand for English teachers post-9/11 and this is also possibly a reason why these respondents emphasise the importance of learning English. English language is (so far) the only major in the Faulty of Arts at KAU which is overloaded with students. This was indicated by the Head of the English Department who stated that:

We, therefore, take the best of the worst. We have to accept a certain quota (120 students per semester) adding to this those students who have failed the beginning courses. I believe the main problem is the number of the students [Personal Communication with the Head of the Department, 2007].

The linking of the importance of English both locally and internationally with a choice of Major and success in that Major is clearly indicated in the following words by Student 15 :

English language is considered the first and the most importance language in the whole world. Learning English language as a second language is very necessary for everybody. For these reasons, I choose English language as my major in (sic) university [St15, Line, 2-3].

\subsubsection{Middle of the Success Stories}

The beginnings of the success stories which emphasised satisfaction with the level of English and the valuing of English were followed up with the middle part of the stories which elaborated on these reasons for success. Personal actions, educational environmental factors (both at Secondary School and University) and external factors were provided as reasons for a high level of English proficiency. The valuing of English was offered as an important personal attitude which affected success.

\subsubsection{The Value of Individual Action}

The 'success story' respondents all reflected the master narrative of individual responsibility for success as reflected in the literature on language learning and motivation (Dörnyei, 2001; Dörnyei, Csizér, \& Németh, 2006; Zoltán Dörnyei \& Ushioda, 2009). These students appear to lean towards a more Western individual conception of culture, rather than collective culture as defined by Hofstede (1983) in common with youth elsewhere. Perhaps this is a phenomenon of youth culture as Meijer (2000) argued, "Arab youth are torn between keeping up with modernization and global culture on the one hand and being [negatively] seen as 'Western' on the other hand"(cited in Karam, 2010, p. 302) and consequently negatively perceived by their local communities. The 'success' narratives described a number of actions the individuals had taken which they believed had contributed to their individual success. These include the following:

I used to read all of my English books, I was also trying to get the meaning of unknown words [St3, Line, 5-7].

And

...practicing the languages (sic) is the most important factor to learn English...and having English speakers helps a lot...should read a lot, memorise some word (sic), proverbs and Adioms (sic) to add to the Above (sic) mentioned practicing English.... this procedure I have fellow (sic) to adopt the English language to my satisfaction [St 21, Line, 6-15].

And

they [the students] should use English everywhere, like (sic) restaurants, hospitals, and with everyone of your friends [St 15,10-12].

These personal actions involve a proactive approach. For example, Student 16 used his knowledge of the language and the ability to self-correct as a tool to improve as in" I can assess and consciously [emphasis by the authors] improve my own pronunciation" [Line 8-9].

\subsubsection{Family Influence and Autonomy}

In contrast to these individual reasons for success, some of the respondents ascribed their 'success' stories to external influences such as that of the family. For example, Student 4, stated that "I started learn (sic) English when I was 12 at school and some books my brother gave me to improve my language in reading" [Line, 5-6]. Student 19 similarly noted that his love for the English language stemmed from his motivation to be like his father as in "I want to know more about English and I love that, because I want to be in one day a dactor (sic) gast (sic) like my father" [Line, 9-10].

Student 21 realistically believed that learning English was not easy "you should study hard and take care of your studying because English language, it's not easy" and "you should be more (sic) practice and more reading, lising (sic), speaking and writing." This respondent linked his individual actions with the need to participate collectively and 
improve English as a group. He stated that to improve English "you should reach in (sic) information and truth and beomice (sic) you couse (sic) you (sic) win" [Line, 5-10] and participate in "small groups, travels" [Line, 13-14].

\subsubsection{Educational Factors}

Most of the individual success stories were linked with actions to self-correct and self-improve. Only one of the respondents emphasised the role of educational influences such as the teacher in his success. Student 22 viewed his university teacher as "very good" since he "explains to us in English and Arabic which helps us to understand everything easily" [Line 22]. However, Student 22 viewed his teacher as 'very good' because he used Arabic to explain things which were difficult for them to comprehend. Here, bilingualism served as a learning tool in the classroom in contrast with the other 'success stories' who valued immersion in the target culture. Student 22 was the only respondent in this study who reflects satisfaction with his university teacher. This satisfaction was attributed to the fact that he (the teacher) uses translation from L1 to ensure comprehension.

\subsubsection{External Influences on Success}

Similarly to the beginnings of the 'success stories', the middle of the stories focussed on the role of the global media and contact with native speakers from the target cultures in English language success and also on how the successful acquisition of English leads to access to the global media and interaction with English-speakers. Here, more details of how they used the different media and interact with English speakers are given.

Students 17 used the media for self-study and advised his fellow students to do the same "I keep practicing and having a lot of on line English friend to communicate with them in English," [Line, 1-2] and "you can also try to talk by English with you'r (sic) friends" [Line, 10] and by "reading the translation below [When watching English movies]" [Line, 6]. Student 4 advised others to take a similar path to himself and to "try to talk every day with a group of people or someone by English language to have good (sic) conversation" [Line, 16].

Other students (St 5, Line 16, St 18, Line 18, St 19, Line 17) emphasised the role of travel and external courses in improving English competence. For example, Student 17 stated that "having some Summer corses (sic) to improve my English more and more" [Line 7-8], while Student 5 stated, "If you want to travel it will help you in your learn" [Line 16]. On the other hand, English communicative competence ensured interaction while travelling as Student 19 noted, "English language is the world language, with it we can travel all around the world" [Line 16-17].

\subsubsection{Valuing of English}

As in the beginnings of the success stories, the importance of English and the value these students place on English is reiterated in the middle of some of the stories. For example, Student 5 noted, "I love this language" [Line 7] and "English is the most important language in the world now" [Line 13]. Student 21 commented on both the importance of learning English "Learning English is very important" [Line 11] and the social and economic imperative to learn English, "You should be person stading (sic) or learning English" [Line 12].

\subsection{The Ends}

All the success stories ended with the students, providing advice to their colleagues. This reflected confidence in their identities as 'successful' English learners and leaders of their colleagues. Student 16, for example, stated that "the selfconfidence is very important for the language learner" [Line 23-24]. This advice was expressed in explicit use of modalised declaratives indicating a strong degree of obligation "students should do a lot of efforts to improve their English" [St 15, Line 17] and "they should use appropriate ways to improve their level of English" [St 16, Line 26-27] and words such as "advice" or "advise" [St 3, Line 13, St 5, Line 17, St19, Line 12, St 20, Line 14].

These endings reflect again the master narratives of the superior nature of certain varieties of English and of individual success. Internalising and valuing these varieties and the notion of the individual as central, is viewed as resulting in success. Student 15 [Line 8-13] reiterates this point of view with the words "they [students] should use English everywhere, like restaurants, hospitals, and with every one of your friends. Don't be shy of making mistakes, because you will learn from your mistakes. Try to hear native speakers on the radio or t.v. (sic) like BBC Channel. Read newspaper, magazines and short stories" and Student 9 notes, "If you love English language, you will learn it very well, like native speakers as the Americans [authors's emphasis]" [Line 19-20].

\subsubsection{The Structure of the Failure Story Narratives}

\subsubsection{Beginnings of Failure Stories}

All the failure stories started with the students' responses to Narrative Prompt 3 focusing on their feelings about their English language abilities which are extremely negative. This dissatisfaction centred on a lack of skills to achieve in their studies, but especially their inability to operate in the 'real world'. Student 11 stated, for example, "I am not satisfied with my level of English ... the subjects are not in order" [Line 1-3], while Student 7 expressed dissatisfaction with his inability to access the media, he stated, "I cannot understand the conversation on TV [Line 7]. The students generally focussed on the difficulty of learning English and denigrated themselves as EFL learners from an Arabic background. For example, Student 13 felt that "perfection level in learning a language is always hard to get, so little or a little more can be enough especially for a student who studies a second language like me" [Line 1-2] and Student 14 stated, "it's very difficult language Arabic speaking people cannot pronounce words correctly and they cannot writing (sic)" [Line 3-6]. 


\subsubsection{The Middle part of the Narratives}

In the middle of the 'failure' narratives the focus was on finding reasons for their failure to achieve a high level in English.

\subsection{The Blame Game}

Most of these respondents blamed others rather than themselves as individuals for their negative feelings towards English and failure in learning the language.

Student 1 and Student 20 bluntly blamed the society as a whole for their failure via the following words: "the main reason is in our society because we can not to (sic) practice our language" [St 1, Line, 2-3] and "no my English language is bad. First of all, society don't speak English, this is the main reason for me" [St 20, Line 1-3].

Four of the respondents blamed their secondary schools for their low level of English with the following words:

also my study (sic) in the primary and secondary school (sic) do not (sic) give me more (sic) information about English language [St 20, Line 2-3].

And

I am not satisfied with my English learning standard Though (sic) I am (sic) studying English from (sic) from my secondary school. I have not learnt English very well” [St 14, 1-6]

And

secondary school my English Teachers (sic) Didnt (sic) Teach (sic) well [St 2, Line 6-7].

Student 11 ascribed this poor teaching to poor attitude among the teachers with the words, "the teacher in the high school does not seem interested in teaching the students the English very well" [Line, 5-6] and thus felt that it resulted in poor student attitude ("the student is also not interested to learn the language" [Line, 6-8]).

The English teaching at university level received the biggest share of the blame. University teachers and their pedagogy, the facilities and the classroom atmosphere were all noted as reasons for poor English skills.

The university teachers' lack of understanding about the students' starting levels of English was reiterated in several of the 'failure' narratives. For example, Student 11 stated that "some of the teachers are teaching the students like the student is the professor" [St 11, Line, 3-4] and Student 8 sadly noted that students should, "never learn English to be focused". He blamed his own and other students problems on the "confusion between ESL and EFL English language" teaching and stated that, "teachers indeed teach a chaotic language for their students, teaching staff advise any English Leaner (sic) not to learn English if he or she wants to stay unconfused, and mentally o.k." [Line 3-6]. This reflected the reality of the curriculum which consisted mainly of literature and comparative linguistics, while the students were still acquiring basic communicative competence in the language.

The styles of pedagogy and classroom environments were also blamed for the students' low levels of English as shown in the following:

many students and me feel lonely in the class so we are unable to study. We are not talking English together [St 7, Line, 16-17].

And

we need more laboratories in order to improve selves (sic)" and "we need a good atmosphere to practice what we learn [St 1, Line, 9-12].

Some of the respondents, like Student 7, blamed individual as well societal factors for their lack of success in English. Student 7, for example, explained that "English language is complex process (sic)... it is (sic) involving many interrelated factors" [Line, 8-10]. He blamed himself for lacking enough motivation to study English "I am Also (sic) To (sic) Blame (sic) for not giving Attention (sic) to this language" [Line, 8-9] but noted that one of the reasons for this lack of motivation was that he thought other subjects were of a greater value "I was giving more Time (sic) to Learn (sic) other subjects and neglecting English language" [Line, 9-10]. This emphasising of other subjects could be due to the fact that comparably little time is spend in KSA high schools on English with the majority of the time spent on Arabic and Islamic subjects.

Student 5 likewise blamed his own feelings of fear towards learning a foreign language for his lack of success. He stated that he "was very scare (sic)" [Line, 2] when he started to learn EFL. However, like the others, he also blamed the fact that he was not provided with enough "experiences and skills" for this problem [Line, 3].

\subsection{Global English}

Like the 'success stories', the 'failure' narratives also emphasised the importance of English as a 'global' language and the language of economic success as noted in the words, "I came to know The (sic) Importance (sic) of this language. This language is the "lingua franca" for Arabic speaking students" [St 2, line, 12-14].

Unlike the success stories which started with the importance of global English, with these respondents described their failure to do things "correctly" and their inadequacies in relation to the 'perfect' native speaker in the middle of their 
narratives as part of an explanation for their lack of success. For example, Student 22 put an immense pressure on himself to do better "I am not satisfied fully. I have to learn more. I must talk in English like native speakers [emphasis by authors]. I must read and write correctly". [Line, 1-3]. Student 14 noted, "It's very difficult language for Arabic speaking people cannot pronounce words correctly and the (sic) cannot writing (sic) some word (sic) correctly [emphasis by authors]" [Line, 1-6].

\subsubsection{Ends of Failure Stories}

Like the success stories, the 'failure narratives' ended with advice. However, unlike the success stories, these students did not set themselves up as the experts. Rather they advised the other students to avoid taking English unless they had outside help, extensive contact with media or immersion in the target culture as indicated by the following:

My advice to that student the one who choose the Department of European language is to know a lot of information.... take [outside] courses in English... you can do that yourself...you can take that course and learn by yourself [St 11 14-19].

And

To develop myself in English...I will try to practice all these by internet, chat, messenger or travelling around the world [St 18, Lines 15-18].

The 'failure' narratives also emphasised the hope that things would be better despite the current difficulties. This reflected an Arabic cultural discourse that all should be left in the hands of Allah. Thus, despite personal effort, success (and in this case failure) is linked to Qadar القداد(Divine Decree), whether good or bad. It is the belief that everything that happens was predestined by Allah and that only He has the power to bring good fortune or bad fortune into one's life. Everything is already 'written' and thus everything is unavoidable as the Qur'an stated in the following:

"Did you not know that Allah knows (all) what in heaven and earth? Verily, all put down in a record. Indeed, that is very easy of Allah (Surah Al-Hajj 22:70)".

Any bad events that happen to humans are already recorded, and they should not feel sorry for themselves as this is not entirely their mistakes as in:

No disaster befalls earth but it is in a record before We created it. Indeed, it is easy of Allah. (Surah Al-Hadeed $57: 22)$

Or in the Hadith:

The Prophet PBUH said, when he answered Jibreel's question about faith: "(It means) believing in Allah, His angels, His Books, His Messengers and the Last Day, and to believe in Al-Qadar (the divine decree) both good and bad".

This hope against hope was reflected in the following student statements:

I hope to get good marks in this semester, INSHALLAH [Allah willing] [St 2, Lines 21-22].

And

I hope to get good marks in this semester INSALLA [Allah willing] [St 14, Lines 21-22].

And

After travelling around the world, I hope to speak English fluently [St 18, Line 18-19].

\subsection{Learning as Journey}

Two of the narratives (Students 10 and 13) did not emphasise either success or failure, but instead focussed on the master narratives of language learning as a "journey" and "long process".

\subsection{Beginnings}

In the beginning of these narratives the students explained that they did not focus on perfection, but instead they emphasised development. Student 13 stated, "perfection level in learning a language is always hard to get, so little, or little more can be enough" [Line, 1-3]. Student 10 emphasised that learning English involved "a long way" [Line, 1], "time" [Line, 18] and that they should be "patient" [Line, 20]

\subsection{Middles}

Student 10, uniquely, appeared positive about his high school English learning experiences with the words, "the teachers [in high school] were so good. And they gave us their experience in learning English and how can we start learning English" [Lines 1-3]. He contrasted this positive learning experience with the many problems at university level as he "did not use English all (sic) time in the class" and the fact that "most of the professors do not understand that most of the students are zero in English. They deal with us as natives" [Line, 11-16]. Thus his language learning journey had gone awry because of the pedagogy and attitude of his teachers. Student 13 evaluated his strengths "I think that my listening and understanding are good, my writing is kind of good too" and weaknesses "But I think I am a little bit weak at speaking directly and having conversations and that is my weak point" [Lines 5-8]. 


\subsection{Ends}

There was still like in the 'success' narratives clear a focus on individual action in order to move forward in their language learning journey in these two narratives For example, Student 10 stated "I advise anyone to be patient, then look for many ways in learning English" [Line, 19-20], while Student 13 promised himself to improve his individual ability by more "practice" [Line, 15].

\section{Conclusion: Global/Information-Age Language Identity}

Except for a few instances (St12, St13, St14, St18), the attitude towards classroom learning at University and High School was negative or dismissive in relation to the actual teaching. Instead, self-study, interactions online and with other media and personal interaction with English native speakers seemed to be valued most highly by the students. Discourses of individual aspiration and self-motivated learning permeated the student narratives in contrast with the Discourses promulgated in the Education system in general. For example, the Tatweer Perspectives and Aspirations (2010, p. 1) state:

The Saudi Arabian government statute which stems from the way of life from Islam and assimilating general education policy which set the general framework of goals, broad education objectives and dependable sources to derive those objectives. Tatweer's curriculum program starts from basic principles that are based on Islam and its moral, ethical and cultural system is an essential point for development, prompts for positions and an entrance to a conscious interaction with diverse cultures in openness era and global village. It is a shared responsibility to preserve the learner's identity, emphasize active citizenship, national belongings, and positive values of society and to ensure its connection, development, and maintenance. The curriculum is the most important affect to achieve. Arabic is the language of Qu'ran, it is conveyed to our society's cultural heritage, to maintain our culture and identity we have to maintain it.

Despite the ambivalence towards the embracing of Western ideologies evidenced in this document which contrasts strongly with its emphasis on "information-age" learning and despite its conception of a collective, fixed, Islamic/ Arabic identity, the students in this study appear to have constructed individual identities unconstrained within the hierarchy of their society. Within these learning identities, they describe themselves as technology natives (St4, St7, St15, St16, St17, St18, St19, St22) and global citizens (Byers, 2005) of the information age (Kluver, 2010). This individual learning identity was vociferously claimed by the students in this study. As one student stated in a follow up focus group:

\section{You know what? They think we are stupid. They think we are kids. They don't treat us like adults. I can know [sic], I can use the net to find more than what they can teach us here. There is no need to hide. (ST.4)}

As Foucault (1980:p.191) suggests, within every productive network there is always the possibility for resistance. This resistance evidenced in the students focusing outwardly in order to access knowledge through the medium of English and also in order to acquire English as represented in Figure 1 in the index.

In order to engage with their students, it has become clear that irrespective of the fears of Westernization and domination in the society in general, the students are immersed in the global media and Western cultures and, therefore, "English language educators must understand the direct and powerful impact of social, political, and economic forces upon their classrooms and how these forces affect students' lives" (Tollefson, 2000, p.19). Their students like youth around the world are exposed to a range of influences beyond the classroom. If KSA educators wish to preserve and foster an 'Islamic identity' in their learners, they need also to accept the other influences on their students' learning identities and understand the complex nature of learning and teaching in this context.

\section{References}

Al-Degether, R. (2009). Teacher educators' opinion and knowledge about critical thinking and the methods they use to encourage critical thinking skills in five female teacher colleges in Saudi Arabia. Unpublished PhD, University of Kansas, Kansas.

Al-Haq, F., \& Smadi, O. (1996). Spread of English and Westernization in Saudi Arabia. World Englishes, 15(3), $307-$ 317.

Al-Issa, A. (2006). The Implication of Implementing a 'Flexible' Syllabus for ESL in the Sultanate of Oman. RELC Journal, 37(3).

Al-Shuaibi, A. (2006). The Role of Media: Between Education and Entertainment. In E. C. f. S. S. a. Research (Ed.), Arab Media in the Information Age (pp. 149-152). Abu Dhabi: Emirates Centre for Strategic Studies and Research.

Azuri, L. (2006). Debate on Reform in Saudi Arabia: The Middle East Media Research Institute

Bakhtin, M. (1981). The dialogic imagination: four essays (C. E. M. Holoquist, Trans.). Austin, Texas: University of Texas Press. 
Bennett, S., Maton, K., \& Kervin, L. (2008). The 'digital natives' debate: A critical review of the evidence. British Journal of Educational Technology, 39(5), 775-786. Retrieved from http://www.blackwellsynergy.com/doi/abs/10.1111/j.1467-8535.2007.00793.x

Benwell, B., \& Stokoe, E. (2006). Discourse and Identity Edinburgh: Edinburgh University Press.

Bourdieu, P. (1986). The Forms of Capital. In J. G. Richardson (Ed.), Handbook for Theory and Research for the Sociology of Education (pp. 241-258). New York: Greenwood Press.

Byers, M. (2005). The Meanings of Global Citizenship. UBC Global Citizenship Speaker Series. Retrieved from http://www.internationalization.ubc.ca/gcss.htm\#Meanings

Canagarajah, A. S. (1999). Resisting linguistic imperialism in English language teaching. New York ; London: Routledge.

Canagarajah, A. S. (2005). Reclaiming the local in language policy and practice. Mahwah, NJ: Lawrence Erlbaum Associates.

Chhuon, V., Kyratzis, A., \& Hudley, C. (2010). Sources of Coherence in the Life Stories of Cambodian American Women at the University. Journal of Language, Identity \& Education, 9(5), 347 - 362.

Clarke, M. (2006). Beyond antagonism? The discursive construction of 'new' teachers in the United Arab Emirates. Teaching Education, 17(3), 225-237.

Clarke, M. (2008a). The discursive construction of an online community of practice. Journal of Pragmatics, 39.23332344.

Clarke, M. (2008b). Language teacher identities: Co-constructing discourse and community. Clevedon: Multilingual Matters.

Clarke, M. (2009). The ethico-politics of teacher identity. Educational Philosophy \& Theory, 41(2), 185-200.

Clarke, M. (2010). Doing identity work in teacher education: The case of a UAE teacher. In R. Sultana \& A. Mazawi (Eds.), World Yearbook of Education 2010: Education and the Arab World: Local Dynamics, Global Resonances (pp. 145-162). New York: Routledge.

Dörnyei, Z. (2001). Motivational Strategies in the Language Classroom. Cambridge: Cambridge University Press.

Dörnyei, Z., Csizér, K., \& Németh, N. (2006). Motivation, Language Attitude and Globalisation: A Hungarian Perspective. Clevedon: Multilingual Matters.

Dörnyei, Z., \& Ushioda, E. (2009). Motivation, Language Identities and the L2 Self: A Theoretical Overview. In Z. Dörnyei \& E. Ushioda (Eds.), Motivation, Language Identity and the L2 Self (pp. 1-9). Ontario, Canada: Multilingual Matters.

Elyas, T. (2008a). The Attitude and the Impact of American English as a Global Language within the Saudi Education System. Novitas-ROYAL (Research on Youth and Language), 2(1).

Elyas, T. (2008b). To be Americanized or not to be: The current debate of English as a global language within the Saudi education system post 9/11. In: Al-Alshikh, M. M.A.-Y., Ali; Al-Shahrani, Farhan; Al-Sherhy, Abdullah, ed. International Saudi Innovation Conference 2008, 2008b Leeds, UK. Saudi Clubs in the UK and Ireland, 98-106.

Elyas, T. (2008c). Identities and relations in pedagogy: The sociocultural meanings and micro politics of classroom interactions from a Saudi perspective. ACTA Inaugural International TESOL Conference 2008. Alice Spring, Australia: ACTA.

Elyas, T. (2008d). Power Relations in Saudi TESOL settings. LingFest 2008. Sydney, Australia: ALAA.

Elyas, T.( 2009a). Not in our religion not in our classrooms: Exploring the cultural tension between Saudi English teachers and students in a Saudi classroom. In: PHAKITI, A. (ed.) 4th University of Sydney TESOL Research Network Colloquium. Syndey.

Elyas, T.( 2009b). Post 9/11 Impact on English Language Curricula in Saudi Arabia: Trends and Reform. In: ZUCKERMANN, G. A. (ed.) First Australian Workshop on Afro-Asiatic Linguistics (AWAAL). Brisbane, Australia.

Fakhro, A. (2006). Impact of Media on Education: Reality and Ambition. In E. C. f. S. S. a. Research (Ed.), Arab Media in the Information Age (pp. 139-148). Abu Dhabi: Emirates Centre for Strategic Studies and Research.

Foucault, M. (1980). Truth and power. In C. Gordon (Ed.), Power/knowledge: Selected interviews and other writings 1972-1977. New York: Pantheon.

Gee, J. P. (1996). Social linguistics and literacies: Ideology in discourses (2nd ed.). London: Taylor \& Francis.

Gee, J. P. (1999a). An introduction to discourse analysis : theory and method. London, New York: Routledge.

Gee, J. P. (1999b). Discourse analysis: Theory and method. London: Routledge.

Giddens, A. (1993). New rules of sociological method (Second ed.). Stanford, CA: Stanford University Press.

Halliday, M. A. (2003). Written Language, Standard Language, Global Language. [Article]. World Englishes, 22(4), 405-418. 
Halliday, M. A. K. (1983. ). On the transition from child tongue to mother tongue. Australian Journal of Linguistics, 3, 201-216.

Hofstede, G. (1983). National Cultures Revisited. Cross-Cultural Research, 18(1 January 1983), 285-305.

Jamjoom, M. I. (2010). Female Islamic Studies teachers in Saudi Arabia: A phenomenological study. Teaching and Teacher Education, 26(3), 547-558.

Kachru, B. (1997). World Englishes and English-using communities. Annual Review of Applied Linguistics, 17, 66-87.

Karam, I. N. (2010). Arab Youth, Education, and Satellite Broadcasting. In A. E. Mazawi \& R. G. Sultana (Eds.), Education and the Arab World (pp. 300-316). New York: Routledge.

Khondker, H. (2004). Gloclaisation as globalisation: Evolution of a sociological concept. Bangladesh e-Journal of Sociology, 1(2). Retrieved from

http://www.bangladeshsociology.org/Habib\%20\%20ejournal\%20Paper\%20GlobalizationHHK,\%20PDF.pdf

Kluver, R. (2010). Globalisation, Informatisation, and Intercultural Communication. Retrieved from http://www.acjournal.org/holdings/vol3/Iss3/spec1/kluver.htm

Krashen, S. (Ed.). (1981). Second Language Acquisition and Second Language Learning. Oxford: Pergamon Press.

Krashen, S. D. (Ed.). (1985). The input hypothesis: Issues and implications. London and New York: Longman

Pavlenko, A. (2001). "In the world of the tradition, I was unimagined": Negotiation of identities in cross-cultural autobiographies. The International Journal of Bilingualism, 5(3), 317-344.

Pennycook, A. (1994). The cultural politics of English as an international language. London; New York: Longman.

Pennycook, A., \& Coutand-Marin, S. (2003). Teaching English as A Missionary Language. Discourse: Studies in the Cultural Politics of Education, 24(3).

Phillipson, R. (1992). Linguistic imperialism. Oxford: Oxford University Press.

Phillipson, R. (1999). Voice in Global English: Unheard Chords on Crystal Loud and Clear. Applied Linguistics, 20(2), 265-276

Roberts, B. (2002). Biographical Research. Buckingham: UK: Open University.

Schiffrin, D. (1996). Narrative as self-portrait: Sociolinguistic constructions of identity. Language in Society, 25, 167203

Scott Rigby, C., Deci, E. L., Patrick, B. C., \& Ryan, R. M. (1992). Beyond the intrinsic-extrinsic dichotomy: Selfdetermination in motivation and learning. Motivation and Emotion, 16(3), 165-185.

Solomonides, I., \& Reid, A. (2009). Understanding the relationships between student identity and engagement with studies. Paper presented at the HERDSA The Student Experience.

Tollefson, J. (2000). Policy and ideology in the spread of English. In J. Kelly Hall \& W. Eggington (Eds.), The sociopolitics of English language teaching. Clevedon: Multilingual Matters.

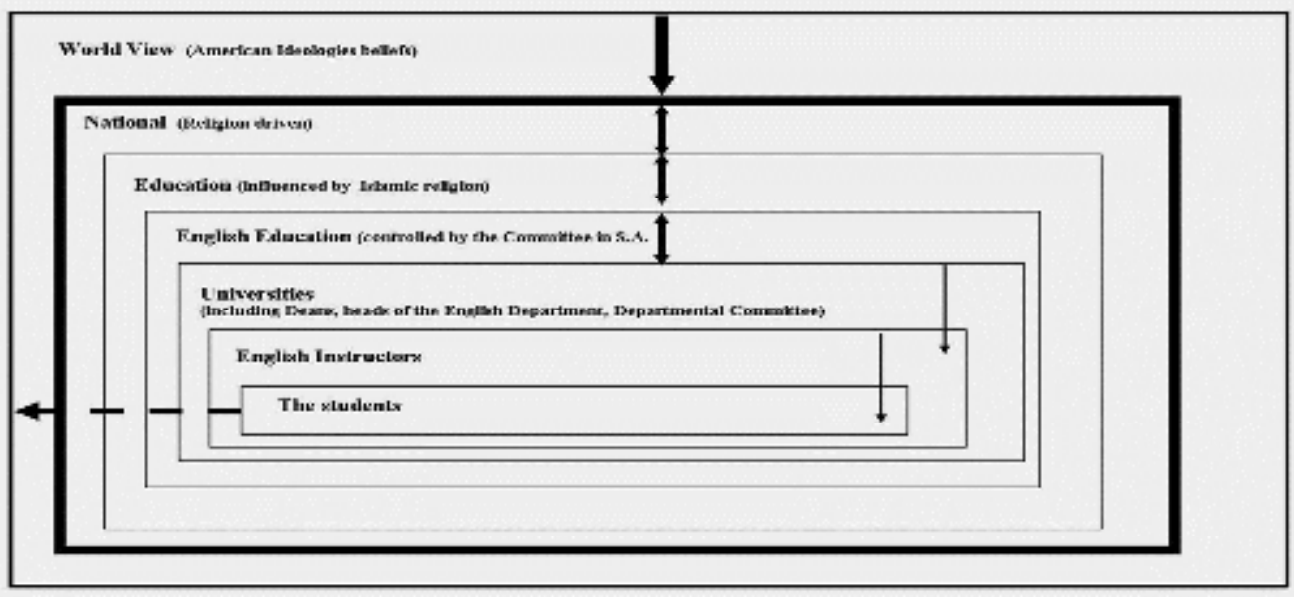

Figure 1. KSA's students seek an alternative knowledge outside their schools 